\title{
OBSERVATIONS ON DOUBLE ALBUMIN. II. A PEPTIDE DIFFERENCE BETWEEN TWO GENETICALLY DETERMINED HUMAN SERUM ALBUMINS *
}

\author{
By DAVID GITLIN, $\dagger$ KARL SCHMID, DAVID P. EARLE AND \\ HARRY GIVELBER \\ (From the Departments of Pediatrics and Medicine, Harvard Medical School, Boston, Mass., \\ and the Department of Medicine, Northwestern University Medical School,
} Chicago, Ill.)

(Submitted for publication December 19, 1960; accepted January 13, 1961)

An unusual serum protein anomaly, the occurrence of two electrophoretically distinct albumins in the same serum, was recently reported by Knedel $(2,3)$ who observed the abnormality in eight members of two different families and termed the condition "double-albuminemia." A similar anomaly was found by Earle, Hutt, Schmid and Gitlin in 25 of 43 individuals in a single family $(4,5)$, and additional families with double-albuminemia have been reported by others $(6-10)$. In all of these studies it was clear that the albumin anomaly was transmitted genetically as an autosomal characteristic, the appearance of two serum albumins in the same individual being a manifestation of the heterozygous state.

In the studies reported by Earle and co-workers, the two albumins proved to be immunochemically and ultracentrifugally indistinguishable from each other and from normal human serum albumin. Differential electrophoretic titration revealed that between $\mathrm{pH} 4.5$ and 10 , albumin $\mathrm{A}$ had a greater net negative charge than had albumin $\mathrm{B}$, but at $\mathrm{pH} 3.5$ and between $\mathrm{pH} 11.6$ and 12.3 both albumins appeared to have the same electrophoretic mobility. The simplest explanation of the data suggested a substitution of either tyrosine, cysteine or lysine in albumin $B$ for a carboxyl residue in albumin A. Albumin A in all respects appeared to be normal human serum albumin, while albumin B was definitely anomalous.

In the study reported here, albumins A and B were hydrolyzed enzymatically and the resultant

\footnotetext{
* Presented in part at the Society for Pediatric Research, May 3, 1960, Swampscott, Mass. (1). This study was supported by grants from the National Institutes of Health (A-251, A-3564 and H-1890) and the Otho S. A. Sprague Foundation.

† Work done as an Established Investigator of the American Heart Association.
}

peptides were compared by electrophoresis and chromatography. The effect of $\mathrm{pH}$ on the net charges of the two albumins was reinvestigated when the data suggested that lysine was the anomalous amino acid in albumin $\mathrm{B}$.

\section{METHODS}

Albumins. Serum was obtained from two adults with double-albuminemia who are members of the family reported earlier by Earle and colleagues $(4,5)$. Each serum was fractionated according to Cohn's Method 10 as described by Lever and co-workers (11) and fraction IV $+\mathrm{V}$ was separated; it contained more than 90 per cent of the total albumin in the original whole serum. Approximately 80 to 85 per cent of the total protein in this fraction was albumin, and it had been ascertained earlier (5) that this fractionation method did not discriminate between albumins $\mathrm{A}$ and $\mathrm{B}$. Albumins $\mathrm{A}$ and $\mathrm{B}$ in each fraction $\mathrm{IV}+\mathrm{V}$ were separated by starch block electrophoresis (12) at $\mathrm{pH} 8.6$ using veronal buffer of ionic strength 0.1 ; the albumins were located in the starch blocks after electrophoresis by means of filter paper prints (5) and were then eluted from the appropriate segments with water. Each albumin was subjected twice again to electrophoresis in starch blocks under the same conditions, since each, particularly albumin B, was usually contaminated with significant amounts of the other in the initial isolation. In this manner, preparations were obtained in which from 85 to more than 95 per cent of the protein was albumin $\mathrm{B}$ as estimated electrophoretically and immunochemically (5) ; the remainder of the protein in these preparations was albumin A. Over 95 per cent of the protein in the preparations of albumin $\mathrm{A}$ appeared to be albumin $\mathrm{A}$ electrophoretically and immunochemically. Three separate isolations of albumins $\mathrm{A}$ and $\mathrm{B}$ were performed with each serum.

Two normal human serum albumin preparations (kindly supplied by Dr. Walter Hughes) were obtained from pools of normal adult plasma by low temperature ethanol-water fractionation according to Method 6 of Cohn and his co-workers (13). Both albumins were crystallized (14) from fraction $\mathrm{V}$, one with the aid of decanol (preparation Decanol 10) and the other as 
the mercury dimer (preparation 187-4X). Both preparations were recrystallized and were extensively characterized physicochemically and immunochemically (14-16). These albumins were dissolved in the same veronal buffer used for the electrophoretic separation of albumins $\mathrm{A}$ and $\mathrm{B}$.

All albumins were dialyzed against distilled water for 24 to 72 hours and lyophilized prior to hydrolysis.

Enzymatic hydrolysis. Twenty to $50 \mathrm{mg}$ of the lyophilized albumins was dissolved in distilled water to a concentration of $0.5 \mathrm{~g}$ per $100 \mathrm{ml}$ and the solutions adjusted to $\mathrm{pH} 8.0$ with $0.1 \mathrm{~N} \mathrm{NaOH}$. The albumins were then denatured by heating to $100^{\circ} \mathrm{C}$ for 15 minutes to 1 hour. The denatured albumins were hydrolyzed in the $\mathrm{pH}$-stat (17) at $\mathrm{pH} 8.0$ and $37^{\circ} \mathrm{C}$ with either chymotrypsin or trypsin using an enzyme:albumin ratio of 1: 50 by weight and using $\mathrm{NaOH}$ for the maintenance of $\mathrm{pH}$. The enzymes were obtained from Worthington Biochemical Corp.; both were bovine in origin and crystallized twice. Digestion was allowed to proceed for 1 to 2 hours, at the end of which time hydrolysis was essentially complete. The hydrolysates were adjusted to $\mathrm{pH} 4.9$ with $0.7 \mathrm{~N} \mathrm{HCl}$; at this point, small amounts of precipitate formed and these were removed by centrifugation. The supernatant hydrolysates were lyophilized and then redissolved in water to a concentration of 50 to $100 \mathrm{mg}$ of original protein per $\mathrm{ml}$.

Separation of peptides. The peptides present in the soluble hydrolysates were separated on sheets of Whatman no. 1 filter paper measuring $23 \times 57 \mathrm{~cm}$. A dry sheet was gently creased in the middle across the long axis and then laid out full length. A pencil line $7 \mathrm{~mm}$ in length was drawn, beginning $3 \mathrm{~cm}$ from one long edge and $1 \mathrm{~cm}$ to one side of and parallel to the middle crease. Two to $4 \mu 1$ of hydrolysate, equivalent to 0.1 to $0.4 \mathrm{mg}$ of albumin, was then applied to an area $1 \times 7 \mathrm{~mm}$ on the dry paper, the application being guided by the pencil line. Application of the hydrolysate was accomplished by using a capillary pipet made by drawing out tubing having an OD of $4 \mathrm{~mm}$ and an ID of $1 \mathrm{~mm}$. The tip of the pipet was fine enough so that the hydrolysates under gentle pressure produced a streak about $0.5 \mathrm{~mm}$ wide when the pipet was drawn slowly across a piece of dry filter paper. After each streak of hydrolysate was applied, the water was allowed to evaporate until the paper was almost but not quite dry and the hydrolysate applied again. In this way, the area of application was kept to the required size. In the waiting periods between streakings, the pipet tip occasionally plugged due to drying; this was rapidly remedied by dipping the tip into distilled water for a brief moment and then wiping the tip against an edge of filter paper.

Two papers were hung in an inverted " $V$ " side by side over three glass rods, $3 \mathrm{~mm}$ in diameter, which were mounted in a rack and the papers were wet and washed at the same time with pyridine-acetic acid buffer of $\mathrm{pH}$ 4.29 ( 0.5 per cent pyridine in $0.2 \mathrm{M}$ acetic acid) or $\mathrm{pH}$ 3.6 ( 1 per cent pyridine in $1.75 \mathrm{M}$ acetic acid) using a $50 \mathrm{ml}$ pipet beginning close to the area of application and working across and down the paper. The buffer was allowed to creep the last few millimeters to and through the application area from both sides. The rack was then immersed in a tank containing Varsol no. 1 (ob)tained from Esso Standard Oil Co.), buffer reservoirs at the bottom of the tank making contact with the short edges of the paper. Electrophoresis was performed at $52 \mathrm{v}$ per $\mathrm{cm}$ of paper for 30 to 80 minutes in the same pyridine-acetic acid buffers used to wet the papers. The Varsol was cooled during electrophoresis by means of cold tap water passing through plastic coils immersed in the tank. The temperature of the tank never exceeded $32^{\circ}$ and rarely exceeded $28^{\circ} \mathrm{C}$; it was usually between $23^{\circ}$ and $25^{\circ} \mathrm{C}$.

After electrophoresis, the papers were dried at $70^{\circ} \mathrm{C}$, rolled into short cylinders and subjected to ascending chromatography for 18 hours in 2,4,6-collidine: 2,6-lutidine: water, in a volume ratio of $1: 1: 1$. The papers were dried at $40^{\circ}$ to $60^{\circ} \mathrm{C}$, unrolled and treated for the detection of either arginine (18), histidine (19), tryptophan (20) or tyrosine (21). Other papers were sprayed with 0.25 per cent ninhydrin in 95 per cent ethanol, and the color was developed by heating to $70^{\circ} \mathrm{C}$ for 15 to 30 minutes and then leaving the papers at room temperature for 1 to 3 days. The peptide patterns were photographed by reflected light, using a light green lens filter and high contrast $35 \mathrm{~mm}$ copying film.

Hydrolysis of peptides and separation of amino acids. Those peptides that appeared to be in different positions in the peptide patterns for the different albumins were cut out of chromatograms which were prepared as described above but sprayed instead with 0.002 per cent ninhydrin in 95 per cent ethanol. The peptides were eluted from the paper with 0.5 per cent $\mathrm{NH}_{4} \mathrm{OH}$ or 1 per cent acetic acid, lyophilized, hydrolyzed in $0.5 \mathrm{ml}$ of 5.7 $\mathrm{N} \mathrm{HCl}$ at $105^{\circ} \mathrm{C}$ for 24 hours in a sealed tube, diluted with $5 \mathrm{ml}$ distilled water, lyophilized, dissolved in $1 \mathrm{ml}$ distilled water, lyophilized again and finally dissolved in $8 \mu \mathrm{l}$ distilled water. Approximately $4 \mu \mathrm{l}$ of the hydrolysate was applied to sheets of no. 1 Whatman filter paper measuring $20 \times 20 \mathrm{~cm}$ and the amino acids chromatographed in two directions, first with water-saturated phenol containing quinolinol (22) and then with collidine, lutidine, and water, $1: 1: 1$.

Electrophoretic mobilities. The electrophoretic molilities of albumins A and B were determined by the freemoving boundary method employing a Perkin-Elmer instrument, model 38. For these determinations fraction IV $+V$ (11) was used throughout. The relative positions of the two albumins on either side of their isoelec tric points had been ascertained earlier (5). Electrophoresis was done over a $\mathrm{pH}$ range of 2.5 to 12.1 for a time period of 1 to 2.5 hours when the two albumins were readily resolved and for 3 to 4 hours when resolution was not evident. The buffers used are indicated in Figure 3.

Titration. The albumins were titrated in $0.1 \mathrm{~N} \mathrm{NaCl}$ using the automatic titrator made by Radiometer Corp., Copenhagen. Sodium hydroxide or $\mathrm{HCl}$ was added by 
means of a calibrated syringe to the protein solution kept at $25^{\circ} \mathrm{C}$ in a double-jacketed water-heated vessel in which the temperature did not vary more than $\pm 0.05^{\circ} \mathrm{C}$. The amount of acid or base added, as well as the $\mathrm{pH}$, was recorded automatically; $\mathrm{pH}$ was accurate to within 0.005 units. The molecular weight of the albumins was taken to be 65,000 (23).

\section{RESULTS}

Hydrolysis with chymotrypsin. Whereas heatdenatured human serum albumin is insoluble in water at $\mathrm{pH} 4.9$, after digestion with chymotryp$\sin 81$ to 94 per cent of the original weight of the albumins remained soluble at this $\mathrm{pH}$. During hydrolysis, from 30 to $36 \mu$ moles of $\mathrm{NaOH}$ per $\mu$ mole of albumin of molecular weight 65,000 (23) was needed to maintain $\mathrm{pH}$. In the peptide patterns obtained with these hydrolysates, approximately 55 peptides could readily be distinguished (Figures 1A and 2). Fifteen of the peptides gave strong reactions for tyrosine, while three additional peptides gave only weak reactions for tyrosine (Figure 1C). One peptide was found that contained tryptophan, ten were found that contained arginine and at least three peptides were found to contain histidine (Figure 1B).

The peptide patterns obtained for each of the albumins were reasonably reproducible whether the patterns were made with the same hydrolysate, with different hydrolysates from the same albumin preparation or with different hydrolysates from different preparations of the same albumin. Reproducible differences between the peptide patterns for albumin A and pooled normal serum albumin could not be detected. In addition, despite careful study, no peptide could be found in the peptide patterns for albumin A or in those for normal albumin that did not have a peptide in the patterns for albumin $B$ analogous in position and type of staining reaction. In the peptide patterns for albumin $B$, however, one peptide was present in a position where no similar peptide was found in the patterns for normal albumin or albumin $\mathrm{A}$.

The distinctive peptide of albumin B (peptide B) carried a relatively high net positive charge at $\mathrm{pH} 4.29$ and $\mathrm{pH} 3.6$; and indeed at $\mathrm{pH} 3.6$, peptide $\mathrm{B}$ was one of the highest positively charged peptides in the patterns.

Tyrosine, tryptophan, histidine and arginine could not be detected in peptide $B$, using the speci-

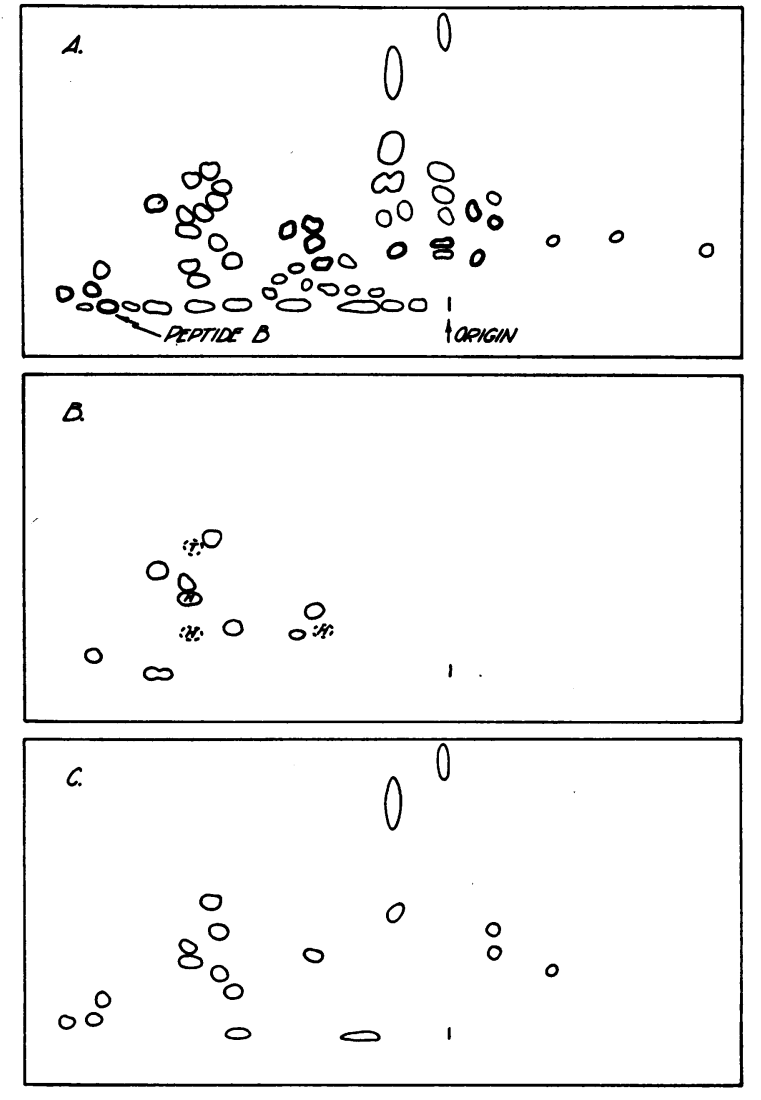

Fig. 1. Composite tracings of peptide patterns obTAINED WITH CHYMOTRYPTIC HYDROLYSATES OF ALBUMIN B. In this and in all subsequent patterns, the direction of electrophoresis is horizontal with the anode to the right of the figure, and the direction of solvent chromatography is vertical. The vertical line indicating the origin was $7 \mathrm{~mm}$ long. A. Developed with ninhydrin. B. Developed for arginine (solid lines), tryptophan ( $T$ ) and histidine $(\mathrm{H})$. C. Developed for tyrosine.

fied staining reactions for these amino acids. Upon isolation of the peptide followed by acid hydrolysis, peptide B was found to yield phenylalanine, lysine, alanine, glycine, glutamic acid and aspartic acid. As controls, areas in the patterns for albumin $\mathrm{A}$ and normal albumin, which were equivalent in size and position to peptide $B$, were also eluted and hydrolyzed with acid; these did yield traces of alanine and glutamic acid.

Hydrolysis with trypsin. From 64 to 81 per cent of the original weight of the albumins remained soluble at $\mathrm{pH} 4.9$ after hydrolysis with trypsin. As with chymotrypsin, this degree of variability in hydrolysis as measured by the relative amounts of soluble and insoluble fractions 

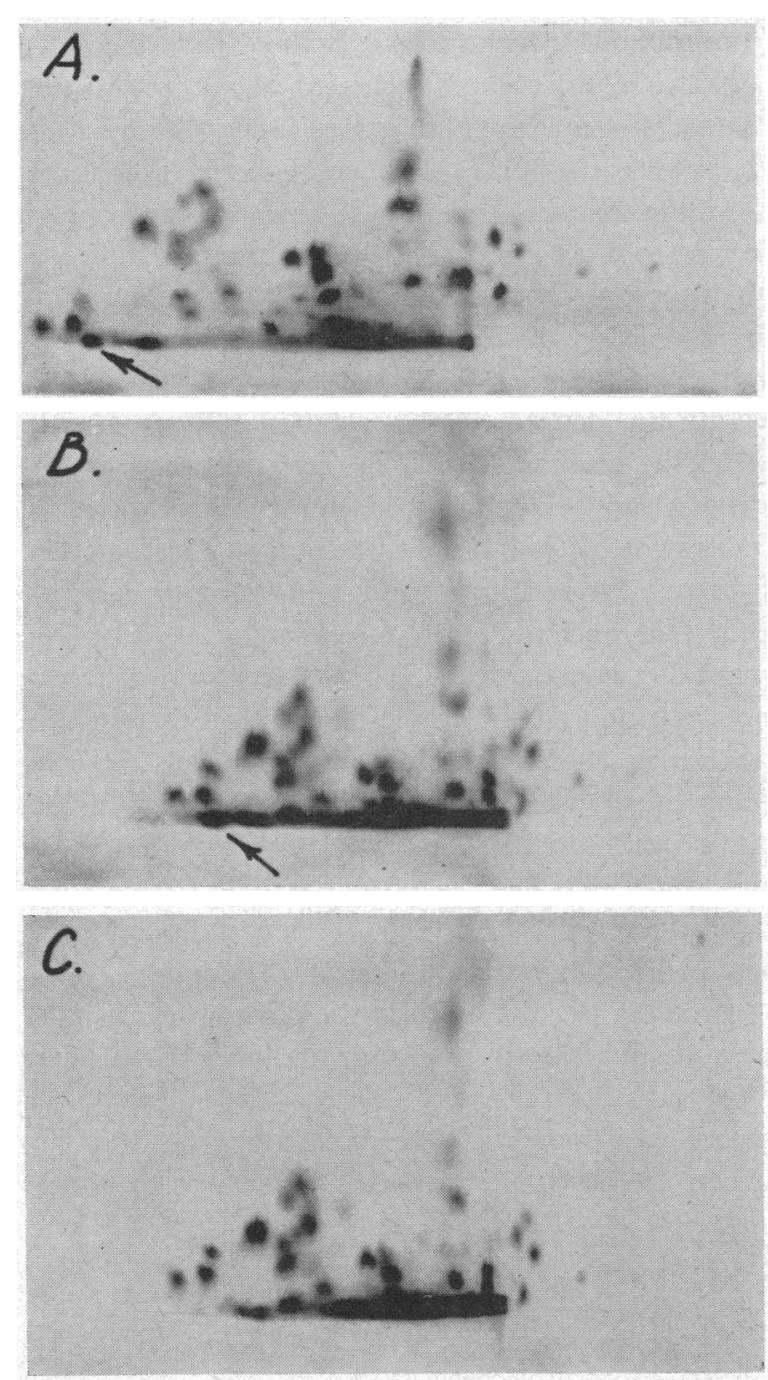

Fig. 2. Peptide patterns obtained with ChymoTRYPTIC hydROLYSATES OF AlbUMin A AND ALbUMin B; DEVELOPED WITH NINHYDRIN. A. Albumin B; electrophoresis for 60 minutes and chromatographed with slightly more than a minimal amount of solvent. Peptide $B$ is indicated by arrow. B. Albumin B, electrophoresis for 45 minutes and chromatographed in a deeper layer of solvent than $\mathbf{A}$; peptide $\mathrm{B}$ is indicated by arrow. C. A1bumin $\mathrm{A}$ run at the same time as $\mathrm{B}$.

did not have a noticeable effect upon the peptide patterns obtained with the soluble portion of the hydrolysates. From 19 to $25 \mu$ moles of $\mathrm{NaOH}$ per $\mu$ mole of albumin was needed during digestion to maintain $\mathrm{pH}$ at 8.0 .

Approximately 55 to 60 peptides were readily detected in the peptide patterns of these hydrolysates when stained with ninhydrin (Figures 3A and 4). Of these, 18 or 19 peptides contained arginine, at least 6 contained tyrosine and 1 contained tryptophan (Figures $3 \mathrm{~B}$ and $3 \mathrm{C}$ ). No reproducible differences could be found between the peptide patterns for albumin $\mathrm{A}$ and for the normal albumins. On the other hand, two peptides were present in the patterns for albumin $B$ that were not apparent in the patterns for the other albumins (Figure 3A).

Elution of the two distinctive peptides of albu$\min B$ with subsequent acid hydrolysis revealed the presence of lysine, alanine, glycine, serine, glutamic acid, aspartic acid and cysteine in the more positively charged peptide, and arginine, serine and glutamic acid in the more negatively charged peptide.

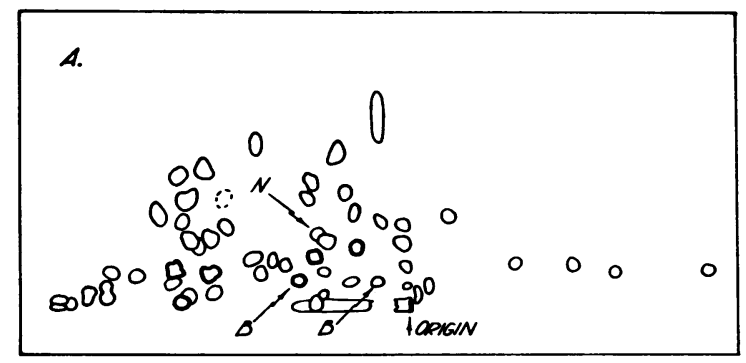

B.
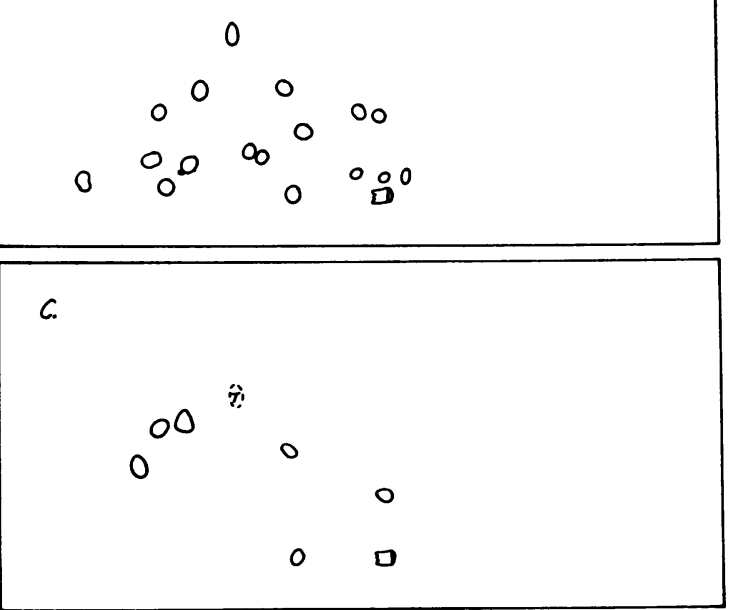

Fig. 3. Composite tracings OF PEPTIDE Patterns OBTAINED WITH TRYPTIC HydRolysates. A. Developed with ninhydrin. Two unique peptides of albumin $B$ and the uncertain peptide of normal albumin and albumin $\mathrm{A}$ (N) are indicated by arrows. B. Developed for arginine. C. Developed for tyrosine (solid lines) and tryptophan $(\mathrm{T})$. 

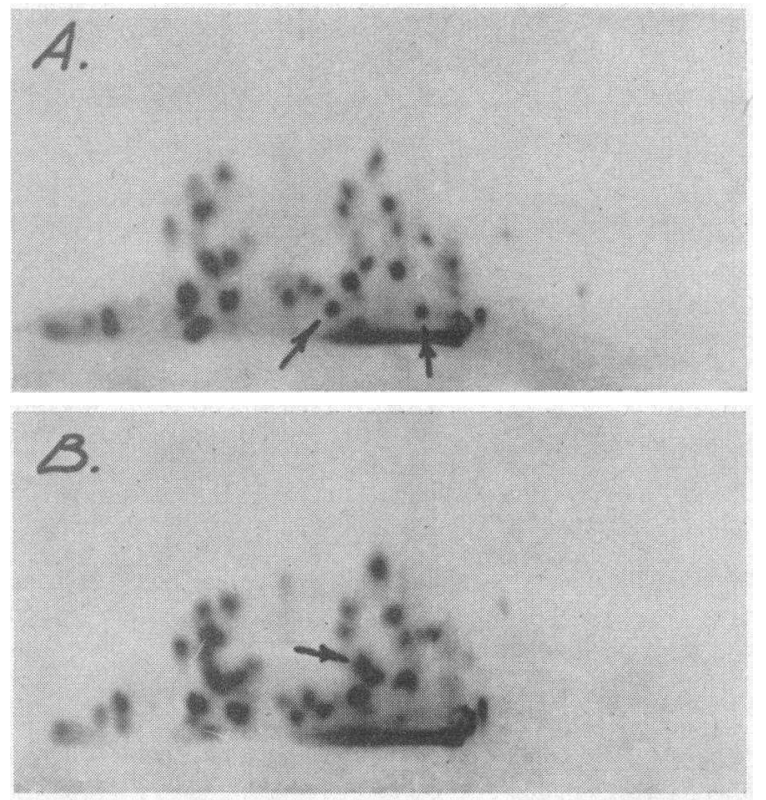

Fig. 4. Tryptic hydrolysates, Developed with Ninhyorin. A. Albumin B; arrows indicate unique peptides. B. Normal serum albumin, preparation Decanol 10 , run at same time as $\mathbf{A}$; arrow indicates the peptide of questionable uniqueness.

In the patterns for albumin $\mathrm{A}$ and in those for normal albumin, one peptide did appear to be present that did not seem to be present in the patterns for albumin B (Figures $3 \mathrm{~A}$ and 4 ); due to close overlapping with another peptide that was present in all of the albumins, the uniqueness of this pepticle could not be established either by elution or by staining reactions.

Difference in net charge between albumins $A$ and $B$ at various $p H$ 's. The electrophoretic mobilities of albumins A and B at various pH's are shown in Figure 5. Between $\mathrm{pH} 4.00$ and 8.43, the difference in the mobilities of the two albumins was fairly constant and averaged $0.55 \times 10^{-5}$ $\mathrm{cm}^{2}$ per volt second; albumin A carries the more negative net charge throughout this range (5). At $\mathrm{pH}$ 9.96, some separation of the two albumins was noted after 4 hours, but at $\mathrm{pH} 10.8$ or higher and at $\mathrm{pH} 3.5$ or lower, the two albumins appeared to have the same mobilities. Interestingly, at or near $\mathrm{pH} 4.0$, neither albumin A nor albumin B appeared to isomerize as does normal serum albumin; this was true whether albumins $A$ and $B$ were electrophoresed as a mixture or separately.

Titration of albumins A and B and normal se- rum albumin preparation Decanol 10 revealed no significant differences between them within the limits of experimental error, and the titration data were the same as those reported previously for preparation Decanol 10 by Tanford (15). By correlating changes in the number of moles of hydrogen ions bound per mole of albumin at different $\mathrm{pH}$ 's with changes in the mobility of albumin A at these pH's (24), it was possible to calculate the degree of change in mobility resulting from the binding or loss of one equivalent of hydrogen ion per mole of albumin. As shown by Longsworth (24) and Schlessinger (25) for other proteins, the resulting change in mobility between $\mathrm{pH} 4.00$ and $\mathrm{pH} 8.43$ for albumin $\mathrm{A}$ was remarkably constant: $0.25 \times 10^{-5} \mathrm{~cm}^{2}$ per volt second per mole $\mathrm{H}^{+}$per mole albumin. Since in this $\mathrm{pH}$ range, the mobility of albumin $\mathrm{B}$ less the mobility of albumin A was $0.55 \times 10^{-5} \mathrm{~cm}^{2}$ per volt second, albumin $\mathrm{B}$ compared with albumin $\mathrm{A}$ at the same $\mathrm{pH}$ had a more positive net charge, equivalent to 2.2 moles $\mathrm{H}^{+}$per mole albumin within the range $\mathrm{pH} 4.00$ to $\mathrm{pH} 8.43$.

Between $\mathrm{pH} 2.5$ and 3.5 the change in mobility of albumin $\mathrm{A}$ with a change in bound hydrogen ions was approximately $0.03 \times 10^{-5} \mathrm{~cm}^{2}$ per volt second per mole $\mathrm{H}^{+}$per mole albumin, and between $\mathrm{pH} 9.96$ and 12.0 this value was approximately $0.04 \times 10^{-5}$.

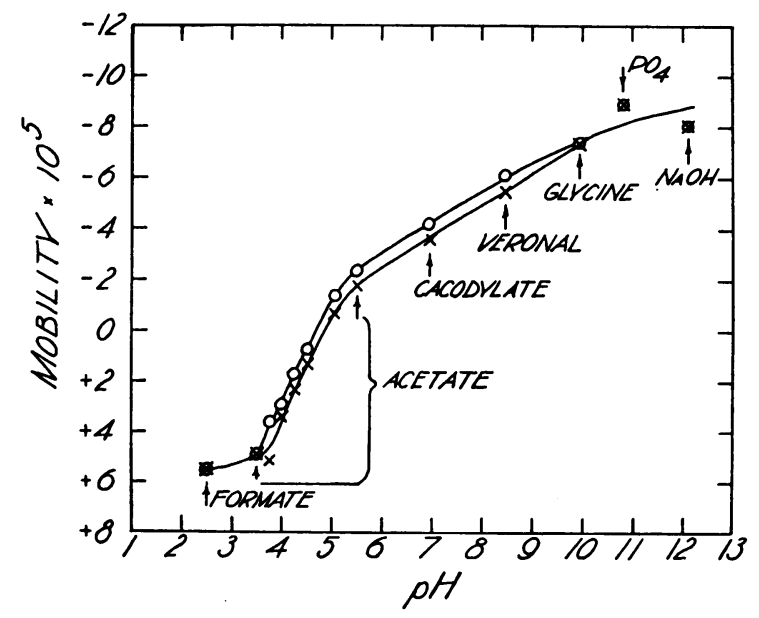

Fig. 5. The eleCtrophoretic MOBILIties OF AlBUMins A (O) AND B $(X)$ AT DIFFERENT PH's. Ionic strength of formate and acetate buffers was 0.1 ; in the remaining buffers, ionic strength due to buffer salts was 0.02 to which was added $\mathrm{NaCl}$ to make the ionic strength of the final solvent 0.1 . 


\section{DISCUSSION}

It is apparent that a difference exists between albumin $\mathrm{B}$ on the one hand and albumin $\mathrm{A}$ and pooled normal albumin on the other in the peptides released from these proteins by enzymatic hydrolysis. The data suggest that this difference is attributable to the presence of a lysine residue in albumin $B$ which is not present in albumin $A$ and normal albumin. The reasons for this conclusion are as follows.

1. It had been demonstrated that, between $\mathrm{pH}$ 4.0 and $\mathrm{pH} \mathrm{10}$, albumin $\mathrm{B}$ had a more positive net charge than albumin $A(4,5)$. On the basis of the charges contributed to serum albumin by the various titratable groups in different $\mathrm{pH}$ ranges, it was suggested that the difference in electrophoretic behavior might be attributed to a substitution of either tyrosine, lysine or cysteine in albumin B for a carboxyl residue in albumin A.

2. In peptide $B$, the anomalous peptide obtained by chymotryptic hydrolysis of albumin $\mathrm{B}$, the only amino acid present with a positive charge at $\mathrm{pH}$ 4.29 or $\mathrm{pH} 3.6$ was lysine; arginine and histidine were both absent. In addition, neither tyrosine nor cysteine was detected in the peptide.

3. Two peptides were found in the tryptic hydrolysates of albumin B that were not present in the tryptic hydrolysates of the other albumins. One of these peptides contained lysine and the other arginine. Since tryptic hydrolysis is limited almost exclusively to bonds involving lysine or arginine, substitution of an amino acid other than lysine or arginine in albumin B would have resulted in the presence of only one anomalous peptide rather than two, unless two amino acids were replaced. Since peptide B did contain lysine and did not contain arginine, it appears that the anomalous amino acid is lysine.

4. The more positive net charge on albumin $\mathrm{B}$ compared with albumin $\mathrm{A}$ in the $\mathrm{pH}$ range of 4.00 to 8.43 was equivalent to approximately two protons per molecule. This is in accord with a substitution of a single lysine residue in albumin $\mathrm{B}$ for a single carboxyl residue in albumin A. Since albumin appears to have but a single peptide chain, substitution of more than one lysine would have resulted in more than two anomalous peptides on tryptic hydrolysis. Admittedly, however, different parts of the albumin chain may be identical in amino acid sequence, and lysine substitutions may have occurred in identical peptide areas to yield but one anomalous peptide with chymotrypsin and two with trypsin. As will be pointed out, however, the number of peptides obtained by chymotryptic hydrolysis did approach the theoretical, suggesting that major portions of the chain at least are not identical. Another possibility is that additional anomalous peptides were present but were not observed in the peptide patterns because of overlapping with nonidentical peptides or were present in the insoluble portion of the hydrolysates.

Obviously, the case for any amino acid substitution could have been much stronger if the peptides of albumin $\mathrm{A}$ and normal albumin which were analogous to the anomalous peptides of albumin B had been isolated and analyzed. Unfortunately, the normal peptide equivalent of the two anomalous peptides released by trypsin could not be identified with certainty, and the nomal peptide equivalent of peptide $B$ released by chymotrypsin could not be located at all. The reasons for the latter failure are not known, although a number of possibilities are apparent. In any event, the peptide patterns appear to support the thesis that albumin $\mathrm{A}$ is normal serum albumin $(4,5)$.

In an earlier study (5), it was pointed out that a lysine-carboxyl substitution did not explain the observation that albumins $\mathrm{A}$ and $\mathrm{B}$ appeared to have the same mobility at $\mathrm{pH} 3.5$ or lower and at $\mathrm{pH} 10.0$ or higher: in the low $\mathrm{pH}$ range, the $\epsilon$-amino group of lysine is ionized but the carboxyl group loses its charge, whereas the reverse is true in the high $\mathrm{pH}$ range. Albumins $\mathrm{A}$ and $\mathrm{B}$ at these $\mathrm{pH}$ extremes would thus still differ by a net charge equivalent to one proton per molecule. In the present study, however, it was found that this difference in charge at these $\mathrm{pH}$ 's resulted in a difference in mobility of only 0.03 or $0.04 \times 10^{-5}$ $\mathrm{cm}^{2}$ per volt second. Separation of the two albumins owing to this small difference in mobility would not be observed under the experimental conditions used, due to various physical disturbances, particularly those caused by the necessity for rapid continuous compensation to keep the albumins within the optical system of the equipment. At $\mathrm{pH} 9.93,4$ hours was needed to begin to see a separation of the two albumins. The failure to resolve the two albumins at the extremes of $\mathrm{pH}$, therefore, was not necessarily owing to the absence 
of a difference in mobility between the proteins but could instead have been due to the fact that the difference was simply too small to permit resolution.

Normal human serum albumin contains 31 phenylalanine, 17 tyrosine, 1 tryptophan, 23 arginine and 55 lysine residues (26). Since chymotrypsin hydrolyzes bonds involving phenylalanine, tyrosine or tryptophan, the total number of peptides found in the chymotryptic hydrolysates, approximately 55, agrees reasonably well with the theoretical number of 50 . The number of tyrosine-containing peptides, 15 to 18 , as well as the single tryptophan-containing peptide, also agrees with the amino acid composition of albumin. For trypsin, however, the total number of peptides found in the soluble hydrolysates, approximately 55, was less than the 79 expected, even though as much as 81 per cent of the albumins did appear in the soluble portion of the hydrolysates. The 18 to 19 arginine-containing peptides were also somewhat fewer than the theoretical number of 23 .

It must be emphasized that, until similar studies are done with the anomalous albumins found in other families with double-albuminemia, the findings obtained with albumin B pertain only to the anomalous albumin found in the family described by Earle and colleagues (4, 5). Most likely, additional types of genetic alteration in the amino acid sequence of albumin will be found. It should also be pointed out that, although the homozygous state for a genetically determined anomalous albumin has not yet been discovered, this, too, remains a real possibility. Consequently, the term paralbumin has been suggested as a generic term for the anomalous albumin (5) and the term paralbuminemia could apply for the homozygous as well as for the heterozygous state. The terms double-albuminemia or bisalbuminemia obviously would not apply to the homozygous states.

\section{SUMMARY}

1. Two genetically determined human serum albumins were hydrolyzed with chymotrypsin and with trypsin. The resulting peptides were separated on filter paper by electrophoresis followed by chromatography. One of the two albumins, A, had the same peptide pattern as did normal human serum albumin. Chymotrypsin released one anomalous peptide from the other albumin, B, whereas trypsin yielded two anomalous peptides.

2. An electrophoretic study of the two albumins indicated that, between $\mathrm{pH} 4.00$ and $\mathrm{pH} 8.43$, albumin $\mathrm{B}$ had a more positive net charge than albumin A, equivalent to two protons per molecule.

3. The data indicate that an anomalous lysine residue is present in albumin $B$ replacing a residue in albumin $\mathrm{A}$ or normal albumin which most likely contains a free carboxyl group.

\section{ACKNOWLEDGMENT}

The authors wish to thank Dr. Dale M. Learned of Kankakee, Ill., for his help in obtaining the sera from the patients with double albumin.

\section{REFERENCES}

1. Gitlin, D., Schmid, K., and Earle, D. P. A peptide difference between normal human serum albumin and a genetically determined human albumin variant (abstract). A.M.A. Amer. J. Dis. Child. 1960, 100, 593.

2. Knedel, M. Die Doppel-Albuminämie, eine neue erbliche Proteinanomalie. Blut 1957, 3, 129.

3. Knedel, M. Über eine neue vererbte Protein-Anomalie. Clin. chim. Acta 1958, 3, 72.

4. Earle, D. P., Hutt, M. P., Schmid, K., and Gitlin, D. A unique serum albumin transmitted genetically. Trans. Ass. Amer. Phycns 1958, 71, 69.

5. Earle, D. P., Hutt, M. P., Schmid, K., and Gitlin, D. Observations on double albumin: A genetically transmitted serum protein anomaly. J. clin. Invest. $1959,38,1412$.

6. Nennstiel, H. J., and Becht, T. Über das erbliche Auftreten einer Albuminspaltung im Elektrophoresadiagramm. Klin. Wschr. 1957, 35, 689.

7. Bennhold, H., Ott, H., and Scheurlen, G. Beiträge zur Frage der gebedingten Blutesweisstörungen. Verh. dtsch. Ges. inn. Med. 1958, 64, 279.

8. Wuhrmann, F. Albumindoppelzacken als vererbbare Bluteiweissanomalie. Schweiz. med. Wschr. 1959, 89, 150 .

9. Franglen, G., Martin, N. H., Hargreaves, T., Smith, M. J. H., and Williams, D. I. Bisalbuminaemia. A hereditary albumin abnormality. Lancet 1960, 1, 307.

10. Miescher, F. Neues Vorkommen der vererbbaren Doppelalbuminämie. Schweiz. med. Wschr. 1960, 90, 1273.

11. Lever, W. F., Gurd, F. R. N., Uroma, E., Brown, R. K., Barnes, B. A., Schmid, K., and Schultz, E. L. Chemical, clinical, and immunological studies on the products of human plasma fractionation. XL. Quantitative separation and determination of the protein components in small amounts of normal human plasma. J. clin. Invest. 1951, 30, 99. 
12. Kunkel, H. G., and Slater, R. J. Zone electrophoresis in a starch supporting medium. Proc. Soc. exp. Biol. (N. Y.) 1952, 80, 42.

13. Cohn, E. J., Strong, L. E., Hughes, W. L., Jr., Mulford, D. J., Ashworth, J. N., Melin, M., and Taylor, H. L. Preparation and properties of serum and plasma proteins. IV. A system for the separation into fractions of the protein and lipoprotein components of biological tissues and fluids. J. Amer. chem. Soc. 1946, 68, 459.

14. Cohn, E. J., Hughes, W. L., Jr., and Weare, J. H. Preparation and properties of serum and plasma proteins. XIII. Crystallization of serum albumins from ethanol-water mixtures. J. Amer. chem. Soc. 1944, 69, 1753.

15. Tanford, C. Preparation and properties of serum and plasma proteins. XXIII. Hydrogen ion equilibria in native and modified human serum albumins. J. Amer. chem. Soc. 1950, 72, 441.

16. Gitlin, D. Use of ultraviolet absorption spectroscopy in the quantitative precipitin reaction. J. Immunol. 1949, 62, 437.

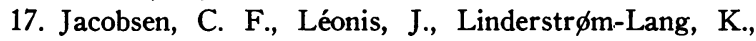
and Ottesen, M. The $\mathrm{pH}$-stat and its use in biochemistry in Methods of Biochemical Analysis, D. Glick, Ed. New York, Interscience Publ., 1957, vol. 4, p. 171.

18. Jepson, J. B., and Smith, I. 'Multiple dipping' procedures in paper chromatography: A specific test for hydroxy-proline. Nature (Lond.) 1953, 172, 1100.

19. Baldridge, R. C., and Lewis, H. B. Diet and the ergothioneine content of blood. J. biol. Chem. 1953, 202, 169.

20. Smith, I. Colour reactions on paper chromatograms by a dipping technique. Nature (Lond.) 1953, 171, 43.

21. Acher, R., and Crocker, C. Réactions colorées spécifiques de l'arginine et de la tyrosine réalisées après chromatographie sur papier. Biochim. biophys. Acta 1952, 9, 704.

22. Wellington, E. F. Amino acids of two insect viruses. Biochim. biophys. Acta 1951, 7, 238.

23. Low, B. W. Preparation and properties of serum and plasma proteins. XXXIV. An X-ray study of crystalline human serum albumin preparations. J. Amer. chem. Soc. 1952, 74, 4830.

24. Longsworth, L. G. Moving-boundary studies on salts and proteins. Canad. Chem. Metall. 1950, 34, 204.

25. Schlessinger, B. S. Electrophoretic and titration study of bovine plasma albumin. J. phys. Chem. 1958, 62, 916.

26. Hughes, W. L. Interstitial proteins: The proteins of blood plasma and lymph in The Proteins, $\mathrm{H}$. Neurath and K. Bailey, Eds. New York, Academic Press, 1954, vol. II B, p. 663. 